\title{
Fraction Sense: An Analysis of Preservice Mathematics Teachers' Cognitive Obstacles
}

TAtik Retno Murniasih ${ }^{1}$, Cholis SA'Dijah ${ }^{\star 2}$, MAKbul Muksar $^{2}$ AND SUSISWO $^{2}$

$\propto$ Research on cognitive obstacles related to fraction sense in preservice mathematics teachers is significant, because their success depends on their skills. The acquisition of fraction sense is a complicated problem requiring a strategy to solve it. This study presents cognitive obstacles with fraction sense tests in preservice who will teach in secondary schools. It focuses on the following categories of cognitive obstacles: epistemological (language representation, tendency to generalise and rely on intuition) and didactic (less meaningful learning, and strategy). This paper takes a qualitative descriptive approach to examine 20 preservice mathematics teachers. The preservice teachers who encountered cognitive obstacles related to fraction sense testing were then grouped based on the similarity of their answers, and seven of them were selected to be interviewed. The research findings showed that five preservice teachers had overlapping obstacles: language representation and tendency to generalise; tendency to generalise and less meaningful learning; language representation, tendency to rely on intuition and trial and error strategy in; language representation and trial and error; and language representation and tendency to rely on intuition.

Keywords: fraction sense, cognitive obstacle, preservice teacher

1 Doctoral Study Program of Mathematics Education, Faculty of Mathematics and Natural Sciences, Universitas Negeri Malang, Indonesia.

2 *Corresponding Author. Faculty of Mathematics and Natural Sciences, Universitas Negeri Malang, Indonesia; cholis.sadijah.fmipa@um.ac.id. 


\section{Razumevanje koncepta ulomkov: analiza kognitivnih ovir bodočih učiteljev matematike}

Tatik Retno Murniasih, Cholis Sa’dijah, Makbul Muksar in Susiswo

$\approx$ Raziskave kognitivnih ovir v povezavi z razumevanjem koncepta ulomkov bodočih učiteljev so pomembne, saj je uspeh učiteljev odvisen od njihovih veščin. Usvojitev razumevanja koncepta ulomkov predstavlja kompleksen problem; za njegovo rešitev je potrebna strategija. V raziskavi so predstavljene kognitivne ovire bodočih učiteljev, ki bodo poučevali v srednjih šolah, na primeru testov razumevanja koncepta ulomkov, pri čemer se raziskava osredinja na naslednji kategoriji kognitivnih ovir: epistemološke (jezikovna predstavitev, težnja po posploševanju in zanašanju na intuicijo) in didaktične (manj smiselno učenje in strategija). Pri preučevanju skupine dvajsetih bodočih učiteljev matematike je bil uporabljen kvalitativni deskriptivni pristop; preizkušanci, ki so naleteli na kognitivne ovire pri testu razumevanja koncepta ulomkov, so bili razvrščeni na podlagi podobnih odgovorov; s sedmimi je bil nato opravljen intervju. Ugotovitve raziskave so pokazale, da so se pri petih bodočih učiteljih matematike ovire prekrivale, in sicer: jezikovna predstavitev in težnja po posploševanju; težnja po posploševanju in manj smiselnem učenju; jezikovna predstavitev, težnja po zanašanju na intuicijo ter po strategiji poskusov in napak; jezikovna predstavitev ter poskusi in napake ter jezikovna predstavitev in težnja po zanašanju na intuicijo.

Ključne besede: razumevanje koncepta ulomkov, kognitivne ovire, bodoči učitelji 


\section{Introduction}

Number sense is defined as a good understanding of numbers and the ability to use them flexibly (Akkaya, 2016; Sadijah, 2013; Yaman, 2015); fractions and decimals are parts of number sense (Way, 2011). Number sense applied to fractions is called 'fraction sense', which is the understanding of fraction concepts, including the relationship between fractions, various representations of fractions, and flexible skills for work with fractions (Fennell \& Karp, 2017; Way, 2011; Woodward, 1998).

Many mathematics experts have researched fraction sense in students (Akkaya, 2016; Ali, 2014; Charalambous \& Pitta-Pantazi, 2005; Jang \& Cho, 2018; Mohamed \& Johnny, 2010; Prediger, 2008; Purnomo, Kowiyah, Alyani, \& Assiti, 2014; Rodrigues, Dyson, Hansen, \& Jordan, 2017; Sa'dijah, 2013; Sengul \& Gulbagci, 2012). In general, these researchers studied the students' difficulties related to fraction relative measurement and the students' low level of skill with decimals, estimation, and fraction representation, including their cognitive obstacles with fraction sense tests. Cognitive obstacles are barriers to thinking, which may be caused by the mental development of the child (ontogenic), less meaningful instruction by teachers (didactic), or difficult mathematics concepts (epistemological) (Bishop et al., 2014; Brousseau, 1997; Osana \& Royea, 2011; Prediger, 2008; Sbaragli et al., 2011). Cognitive obstacles caused by children's mental development can disappear with age (Brousseau, 1997).

One of the causes of students' cognitive obstacles with fraction sense is less meaningful teaching by teachers, so that the students could not complete the fraction sense tests (Cortina, Visnovska, \& Zúñiga, 2014; Prediger, 2008) and found the fraction topic difficult (Lortie-Forgues, Tian, \& Siegler, 2015; Ormond, 2012; Yoshida \& Sawano, 2002). Therefore, students' cognitive obstacles related to fraction sense tests are induced by teachers' inability to assist students in solving the obstacles.

Based on the explanation above, research on cognitive obstacles in fraction sense assignments was conducted on both students and teachers. However, studies on cognitive obstacles with fraction sense assignments in preservice mathematics teachers have rarely been carried out (Newton, 2008; Olanoff et al., 2016; Whitacre \& Nickerson, 2016). Some researchers studied the preservice teachers' difficulties with fractions (Manfreda Kolar, Hodnik Čadež, \& Vula, 2018; Osana \& Royea, 2011; Son \& Lee, 2016). These researchers analysed preservice teachers' cognitive obstacles in fraction sense assignments, focusing on the didactic and epistemological categories. The ontogenic category was not analysed since, theoretically, obstacles caused by children's mental development 
should diminish with age (Brousseau, 1997). Fraction topics are studied since elementary school, so the researchers assumed that there were no preservice teachers with ontogenic obstacles.

Research on cognitive obstacles related to fraction sense assignments is crucial, because it aids in understanding how these obstacles can be minimised. Meanwhile, most of the previous decade's research on preservice mathematics teachers related to fraction sense tests studied the fraction sense strategy used, the preservice teachers' low performance in the fraction domain, their understanding of representation and computation skills, their reasoning of fraction amounts, and their mental calculation (Courtney-Clarke \& Wessels, 2014; Lemonidis, Tsakiridou, \& Meliopoulou, 2018; Şengül, 2013; Son \& Lee, 2016; Whitacre \& Nickerson, 2016; Yang, Reys, \& Reys, 2009). Consequently, a set of information is further required to acknowledge preservice teachers' cognitive obstacles on fraction sense tests.

\section{Theoretical background}

\section{Fraction sense}

Preservice mathematics teachers with good fraction sense usually have the skill and expertise needed to manage fractions. However, the fact is that most preservice teachers' skills in fraction sense remain low (Courtney-Clarke \& Wessels, 2014; Iuculano \& Butterworth, 2011; Lamberg \& Wiest, 2014; Sengul \& Gulbagci, 2012; Whitacre \& Nickerson, 2016; Yaman, 2015; Yang, Reys, \& Reys, 2009). Such skills are used not only when doing mathematical calculations, but also in daily life. For example: If we have an income of six million rupiah and is used for household needs, is paid as taxes, and is for children's education $\frac{1}{3}$ we can calculate the income left over. Fraction sensẹ is also useful as the starting point for understanding the concepts of measurement, geometry, algebra, and data analysis (Purnomo, Kowiyah, Alyani, \& Assiti, 2014). Someone who calculates through algorithms does not have fraction sense (Chattopadhyay, Sarkar, \& Koner, 2017). Most preservice teachers used algorithms in completing mathematical calculations without attempting to give answers that make sense (Olanoff et al., 2016), which is inappropriate, since mathematical calculation should be completed not only by using an algorithm, but also using a strategy that makes sense.

According to Way (2011), fraction sense has the following components: a) understanding fractions as a language and as written symbols, b) understanding the relationship between the number of parts and the relative size of the parts, c) having a sense of the size of the fractions in relation to the whole, 
and d) being able to visualise and make fraction representations with diverse models. In Figure 1, we adapted the idea of number sense problems and numeration to fraction sense.

Figure 1. Number sense and numeration. Adapted from Ontario Ministry of

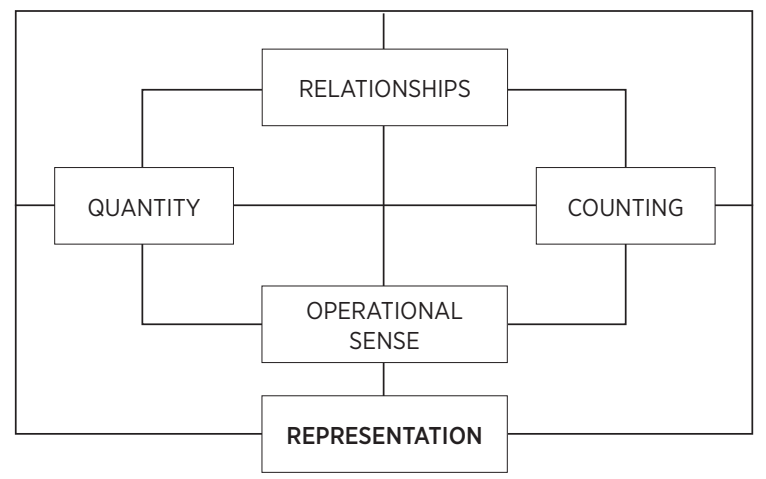

Education, 2016.

The five ideas of number sense and numeration (counting, operational sense, quantity, relationships and representation) shown in Figure 1 are related each other conceptually. In number sense, counting is the reading of a series of numbers in sequence. The conceptualisation of symbols in counting is a representation of quantity. In fraction sense, counting is generally left implicit where there are still other fractions between and , such as, , and others (Simon,

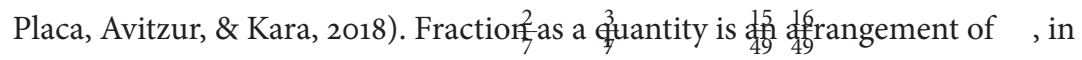
which the whole is arranged into $n$ identical (super-imposable) parts, and $\frac{m}{n} n$ of those parts are designated as the measure, amount, or quantity (Simon, 2006). For example, is defined as having the size of 4 parts out of 7 equal parts.

Relatiofiships between numbers that are well understood help to make mathematical connections. For example, the relationships between 2 and 6 are similar to the relationships between 12 and 16 , since $6-2=16-12$. These relationships involve the operational sense of reduction. Relationships also involve counting, quantity, and the operational sense, which ultimately refers to distance or sequence representations. An example of a relationship in fraction sense is the following: the relationship between and is the same as the relationship between and , since - yields the $\frac{3}{7}$ ame reșssult as - . To find the difference of and , as $\frac{6}{7}$ well as $\frac{3}{7} \frac{2}{7}$ and , involves operatio $\frac{6}{7}$ al ${ }_{7}^{5}$ sense, which in fractions is ${ }_{7}^{3}$ the ua derstanding of fraction operations, the characteristics of fraction operations, and the relationships between them (Alenazi, 2016). The 
counting, quantity, relationships, and operational sense result in distance representation, since and have equal distance between them as and, namely . In other cases $\frac{2}{7}$ ractiơ 3 ns can also be represented as symbols, $\frac{5}{7 g}$ ures $\frac{6}{7}$ and written language (Murniasih, Sa'dijah, Muksar, \& Susiswo, 2018).

\section{Obstacles and fraction sense}

Cornu (1991) differentiates obstacles and learning limits into four types: cognitive, ontogenic, didactic, and epistemological obstacles. According to Cornu (1991), cognitive obstacles occur when a difficulty arises in the learning process; ontogenic obstacles occur in accordance with the child's mental development stages; didactic obstacles take place because of less meaningful teaching by the teacher; epistemological obstacles are caused by difficult mathematics concepts. Brousseau (1997) challenge Cornu's definitions of obstacles. He stated that knowledge acquisition occurs in a complex interaction between students, teachers, and the knowledge system (Brousseau, 1997). In this model, it is difficult to divide obstacles to learning into types. Obstacles can be caused by ontogenic development, a difficult lesson, and less meaningful teaching conducted by teachers. Brousseau (1997) stated that cognitive obstacles could be ontogenic, didactic, and epistemological.

The classifications of obstacles according to Cornu and Brousseau are shown in Figure 2.

Figure 2. The difference in obstacle classification, according to Cornu (1991)

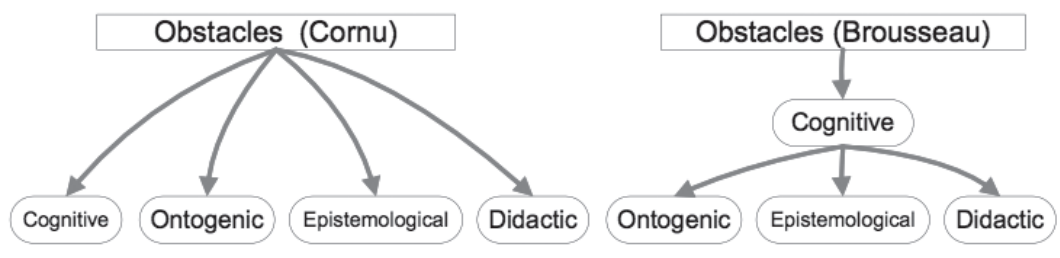

and Brousseau (1997).

Cognitive obstacles in fraction sense tests are most likely influenced by didactic and epistemological obstacles as well (Prediger, 2008; Purnomo, Kowiyah, Alyani, \& Assiti, 2014; Sbaragli et al., 2011; Yoshida \& Sawano, 2002). Didactic obstacles in teaching fractions could happen because of the teacher's practices (Pinilla, 2007). The research results of Prediger (2008) indicate that the didactic category was used to analyse conceptual change obstacles when moving from integers to fractions. For example, How the teacher observes the obstacles of students' thinking process when teaching changes from the concept 
of integers (there are no numbers between 5 and 6) to the concept of fractions (there are many fractions between and ). According to Purnomo, Kowiyah,

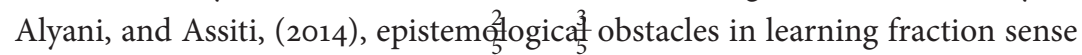
occur when someone does not understand fraction density. For example, the students' mistakes related to the density of fractions: the students stated that there was no fraction between and ; this was because the students linked their pre-existing knowledge of $\frac{40}{69}+\operatorname{lige}_{69}^{41}$ to fractions, and said that there was no number between 40 and 41. Meanwhile, according to Bishop et al. (2014), a cognitive obstacle is a piece of useful knowledge for solving a particular problem, but one that generates a contradiction when it is applied in the new context. The tendency to generalise the result of positive integer's multiplication to be bigger than its two factors is not applicable in the positive fraction multiplication. For instance, in the multiplication of multiple integers of $3 \times 5$ equals to 15 , in which $15>3$ and $15>5$. Meanwhile, in the multiplication of positive fractions of $x$ equals to , in which $<$ and $<$.

$\frac{1}{3} \quad \frac{1}{5}$ Obstacle 15 play an essentiłl role $\underset{15}{11}$ learning, since they force the learners to modify and adjust some aspects of their mindset in resolving the contradiction. Bishop et al. (2014) recommended researching cognitive obstacles based on a specific problem that is considered difficult using a test conducted in a low-performance school. An example of a cognitive obstacle that may occur when learning fractions is difficulties with equal-partitioning and equal-whole relationships (Yoshida \& Sawano, 2002). Up to that point, the students have been taught fraction representation with similarly partitioned units, which may become an obstacle for students when they encounter fraction representation with unequal partitions.

\section{Research question}

In general, this study aims to analyse preservice mathematics teachers' understanding of the size of fractions, which is related to fraction sense. We want to answer the following questions:

1. How can we identify preservice mathematics teachers' cognitive obstacles in understanding the size of fractions?

2. What are the factors that cause the preservice mathematics teachers' cognitive obstacles in understanding the size of fractions? 


\section{Methodology}

This research was conducted using qualitative descriptive data. Preservice mathematics teachers' cognitive obstacles related to fraction sense were analysed based on the accomplishment of a written test and an interview.

\section{Sample}

The research participants were drawn from a group of 69 preservice mathematics teachers who will teach in secondary schools in one of the private universities in Malang City, Indonesia, who intend to teach in secondary schools. These preservice teachers were students who had taken the courses Mathematics Principles and the Mathematics Instruction in School I. Both courses were designed to help the participants understand fractions.

The 69 candidates were asked to complete an initial test on fractions. They were then ranked from lowest to highest based on their test scores. Then, 20 representative preservice mathematics teachers were selected for the study: eight people with the lowest rank ( $\mathrm{X}_{1}, \mathrm{X}_{2}, \mathrm{X}_{3}, \mathrm{X}_{4}, \mathrm{X}_{5}, \mathrm{X}_{6}, \mathrm{X}_{7}$, and $\mathrm{X} 8$ ), seven with middle rank $\left(\mathrm{X}_{9}, \mathrm{X}_{10}, \mathrm{X}_{11}, \mathrm{X}_{12}, \mathrm{X}_{13}, \mathrm{X}_{14}\right.$, and $\left.\mathrm{X}_{15}\right)$, and five with the highest $\operatorname{rank}\left(\mathrm{X}_{16}, \mathrm{X}_{17}, \mathrm{X}_{18}, \mathrm{X}_{19}\right.$, and $\left.\mathrm{X}_{20}\right)$.

\section{Instruments and measures}

The instruments employed in this study were 1) a test consisting of one question; 2) a recording device; 3 ) interview guidelines and 4) a field note. The test was given to establish the cognitive obstacles in fraction sense problems. The test with fraction sense problems was adapted from Clarke, Roche, and Mitchell (2011). The problems were designed to measure preservice mathematics teachers' cognitive obstacles related to understanding the size of fractions. The test was also used to measure cognitive obstacles based on mistakes in answers. The test sheets were distributed to 20 selected preservice teachers. Afterwards, interviews were conducted to investigate whether the cognitive obstacles occurring should be classified as didactic or epistemological. The test that was given can be seen in Figure 3 .

The numbers 4, 3, 1, 6, 5, and 7 are given. Each number can only be used once. Make two fractions, in which the numerator and denominator each contains one number, so that if the fractions are added together, the sum will be closest to 1, but not actually 1 .

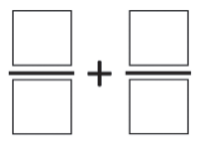

Figure 3. The fraction sense test. Adapted from Clarke, Roche, \& Mitchell, 2011. 
The focus of this study was on the preservice teachers' understanding of the size of fractions. The indicators of cognitive obstacles in the fraction sense test can be seen in Table 1, and the categories of cognitive obstacles in Table 1 are adapted from the previous research. They include the tendency to generalise (O4 and $\mathrm{O}_{5}$ ) (Bishop et al., 2014; Yoshida \& Sawano, 2002); the tendency to rely on intuition (O6) (Purnomo, Kowiyah, Alyani, \& Assiti, 2014); less meaningful learning $\left(\mathrm{O}_{7}\right)$ and strategy (O8) (Pinilla, 2007; Olanoff et al., 2016; Prediger \& Wessel, 2010). The category of cognitive obstacles ( $\mathrm{O}_{1}, \mathrm{O}_{2}$, and $\left.\mathrm{O}_{3}\right)$ was added based on the theory shown in Figure 1 (representation).

Table 1

Cognitive obstacles, their indicators, and their classification by type

\begin{tabular}{|c|c|c|c|}
\hline \multicolumn{2}{|c|}{ Cognitive obstacles } & Indicators & $\begin{array}{l}\text { Types of } \\
\text { obstacles }\end{array}$ \\
\hline \multirow{6}{*}{ Epistemological } & \multirow{3}{*}{$\begin{array}{l}\text { Language } \\
\text { representation }\end{array}$} & $\begin{array}{l}\text { The preservice teachers understand 'clos- } \\
\text { est to } 1 \text {, but not actually } 1 \text { ' to mean two } \\
\text { fractions with an ordered numerator and } \\
\text { the same denominator, for example: } \frac{6}{7} \text {, or } \\
\frac{8}{7} \text {, the closest to } \frac{7}{7} \text { (the obstacle of lan- } \\
\text { guage representation defined as fraction } \\
\text { order) }\end{array}$ & 01 \\
\hline & & $\begin{array}{l}\text { The preservice teachers used a given } \\
\text { number more than once (the obstacle of } \\
\text { representation from language to symbol) }\end{array}$ & $\mathrm{O} 2$ \\
\hline & & $\begin{array}{l}\text { The preservice teachers chose the addition } \\
\text { of a fraction with a distance of } 0 \text { from } 1 \\
\text { (the obstacle of language representation } \\
\text { when interpreting 'distance of } 0 \text { from } 1 \text { ') }\end{array}$ & $\mathrm{O} 3$ \\
\hline & \multirow{2}{*}{$\begin{array}{l}\text { The tendency to } \\
\text { generalise }\end{array}$} & $\begin{array}{l}\text { The preservice teachers added the fraction } \\
\text { by adding the numerator and numerator as } \\
\text { well as denominator and denominator }\end{array}$ & $\mathrm{O} 4$ \\
\hline & & $\begin{array}{l}\text { The preservice teachers relied on pre-ex- } \\
\text { isting knowledge of integers and decided } \\
\text { that the numbers closest to } 1 \text { were } 0 \text { or } 2 \text {. }\end{array}$ & 05 \\
\hline & $\begin{array}{l}\text { The tendency to rely } \\
\text { on intuition }\end{array}$ & $\begin{array}{l}\text { The preservice teachers did not mention } \\
\text { the fraction density }\end{array}$ & 06 \\
\hline \multirow{2}{*}{ Didactic } & $\begin{array}{l}\text { Less meaningful } \\
\text { learning }\end{array}$ & $\begin{array}{l}\text { The preservice teachers forgot the numera- } \\
\text { tor and denominator. }\end{array}$ & 07 \\
\hline & Strategy & $\begin{array}{l}\text { The preservice teachers used a trial and er- } \\
\text { ror strategy, not a fraction sense strategy. }\end{array}$ & O8 \\
\hline
\end{tabular}

During the activity, this study used visual and voice recording devices. The visual recording device was used to record the preservice mathematics teachers' facial expressions while they did the assignment. The voice recording device was used to record the interviews. After that, we took field notes while we observed 
the preservice teachers working on the questions, and while they answered the interview questions. The selection of interview subjects can be seen in Figure 4.

\section{Processing data}

The preservice mathematics teachers were given a fraction sense assignment, and their answers were analysed. Those who answered the question correctly were not interviewed. The preservice teachers who made mistakes were grouped based on their answers, and one representative from each group was chosen for an interview. After that, the answers were categorised based on cognitive obstacles. The researchers followed an interview guideline when they interviewed the preservice teachers, discussing their cognitive obstacles more thoroughly. This was done based on the recommendations of Bezpalko, Klishevych, Liakh, and Pavliuk (2016), who stated that interview guidelines are useful for investigating a particular problem more thoroughly.

The selection of preservice mathematics teachers to be interviewed can be seen in Figure 4.

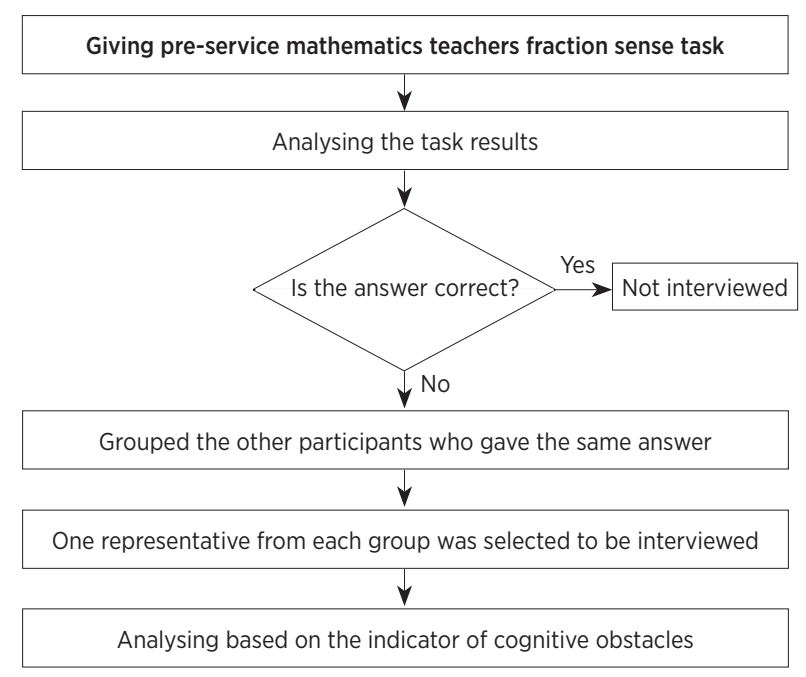

Figure 4. Selection of preservice mathematics teachers for interviews.

Data analysis in this study followed the stages defined by Milles \& Huberman (2009): transcribing the collected data, validating the data, interpreting the data, and drawing a conclusion. Transcribing the collected data included making a verbal data transcript of the preservice teachers' opinions, making an interview data transcript, making a duplicate of the completed assignment, and arranging the data by category. The next stage was examining the preservice teachers' work, recordings, 
field notes, and interview results. The collected data were reduced to focus on the data that were relevant to the research. The data were classified and coded based on the assigned category. Subsequently, the data were validated using source triangulation. The next step was interpreting the data description results, namely the preservice mathematics teachers' cognitive obstacles in the fraction sense problem. A conclusion was then drawn from the data obtained from all analyses.

\section{Results}

The right answer to the question in Figure 3 is $\frac{5}{6}+\frac{1}{7}$. Based on the estimation and benchmark, the two largest fractions are $\frac{6}{7}$ and $\frac{5}{6}$. If $\frac{6}{7}$ is chosen, the remaining numbers in the question cannot be used to form a fraction that, when added, yields a number close to 1 , but not 1 . This means that $\frac{5}{6}$ should be chosen. Then, the remaining numbers are used to form the second fraction, which should be smaller than $\frac{1}{6}$. The only possible second fraction is $\frac{1}{7}$, since the addition of $\frac{5}{6}+\frac{1}{7}$ will result in the fraction that is closest to 1 and is not 1 . Only $10 \%$ out of the twenty participants answered correctly. This amounted to two preservice teachers, $\mathrm{X}_{19}$ and $\mathrm{X}_{2} \mathrm{O}$, who used a fraction sense strategy by counting the fractions flexibly and efficiently, which shows that they have a strong and flexible understanding of fractions and the relationships between them.

The fraction sense test can be seen in Figure 3. Based on the answers they gave, 18 out of 20 preservice teachers had cognitive obstacles in understanding the size of fractions. The incorrect answers given by the preservice mathematics teachers are presented in the following Table 2.

Table 2

Incorrect answers given by 18 out of 20 preservice mathematics teachers on a test involving the sizes of fractions

\begin{tabular}{lc}
\hline Preservice teachers (Percentage) & Answer \\
\hline X1 (5\%) & $\frac{4}{3}+\frac{3}{4}$ \\
X2 (5\%) & $\frac{5}{4}+\frac{7}{6}$ \\
X3 (5\%) & $\frac{3}{4}+\frac{1}{6}$ \\
X4, X5 (10\%) & $\frac{4}{7}+\frac{1}{3}$ \\
X6, X7, X8, X9, X10, X11, X12, X13, X14 (45\%) & $\frac{3}{4}+\frac{1}{5}$ \\
X15, X16 (10\%) & $\frac{4}{5}+\frac{1}{6}$ \\
X17, X18 (10\%) & $\frac{1}{3}+\frac{4}{6}$ \\
\hline
\end{tabular}


The preservice mathematics teachers with cognitive obstacles were grouped based on their answers. Those who gave similar answers were grouped together. After that, seven representative preservice teachers were selected to be interviewed for in-depth analysis. $\mathrm{X}_{1}$ represented the answer $\frac{4}{3}+\frac{3}{4}, \mathrm{X}_{2}$ represented $\frac{5}{4}+\frac{7}{6}, \mathrm{X}_{3}$ represented $\frac{3}{4}+\frac{1}{6}, \mathrm{X}_{5}$ represented $\frac{4}{7}+\frac{1}{3}, \mathrm{X}_{11}$ represented $\frac{3}{4}+\frac{1}{5}, \mathrm{X}_{15}$ represented $\frac{4}{5}+\frac{1}{6}$, and $\mathrm{X}_{17}$ represented $\frac{1}{3}+\frac{4}{6}$. Those preservice teachers were selected as representatives because they had good communication skills and were willing to allocate time for the interview. The interview was conducted outside class time. The results of the interviews with the seven preservice teachers can be seen in Table 3.

Table 3

Responses of seven preservice teachers during the interview

\begin{tabular}{|c|c|c|c|}
\hline Number & $\begin{array}{l}\text { Preservice } \\
\text { teachers }\end{array}$ & Preservice teachers' responses during interview & $\begin{array}{c}\text { Types of } \\
\text { obstacles }\end{array}$ \\
\hline 1 & $\mathrm{X} 1$ & $\begin{array}{l}\text { The preservice teacher } \mathrm{X} 1 \text { chose } \frac{4}{3}+\frac{3}{4} \text { because } \frac{4}{3}+\frac{3}{4}=\frac{7}{7} \text {. } \\
\text { This teacher used the same numbers more than once. This } \\
\text { teacher also correlated with the pre-existing knowledge } \\
\text { of integers, and when he was given a fraction problem, } \\
\text { he generalised by adding the denominators as well as the } \\
\text { numerators. This teacher said that the closest number to } 1 \\
\text { but which is not } 1 \text { is } 0 \text { distance from } 1 \text {. }\end{array}$ & $\mathrm{O} 2, \mathrm{O} 3, \mathrm{O} 4$ \\
\hline 2 & $\mathrm{x} 2$ & $\begin{array}{l}\text { The preservice teacher } \mathrm{X} 2 \text { chose } \frac{5}{4}+\frac{7}{6} \text { and his reasons } \\
\text { were that the numerators should be smaller than the } \\
\text { denominators, and that the numerator should be close to } \\
\text { the denominator. However, the teacher thought that the } \\
\text { numerator was the denominator and vice versa. Preservice } \\
\text { teacher } X 2 \text { also stated that the sum of } \frac{5}{4}+\frac{7}{6} \text { is equal to } \\
\text { with } 1+1=2 \text { (this teacher stated that the number } 2 \text { was } \\
\text { close to the number } 1 \text { ). }\end{array}$ & O5, 07 \\
\hline
\end{tabular}

The preservice teacher $\times 3$ had initially tried other answers,

namely $\frac{3}{5}+\frac{1}{7}=\frac{21+5}{35}=\frac{26}{35}$ and $\frac{3}{5}+\frac{1}{4}=\frac{12+5}{20}=\frac{17}{20}$, and namely $\frac{3}{5}+\frac{1}{7}=\frac{21}{35}=\frac{26}{35}$ and $\frac{3}{5}+\frac{1}{4}=\frac{20}{20}=\frac{12}{20}$, and
finally decided on the answer $\frac{3}{4}+\frac{1}{6}=\frac{9+2}{12}=\frac{11}{12}$ since $\frac{11}{12}$ is the closest number to 1 . After that, the preservice teacher $\mathrm{X} 3$ drew a number line and divided the number line between 0 and 1 into 12 parts, and then positioned to the left of 1 .

The preservice teacher $X 5$ relied on feeling when he chose a fraction that could be easily represented in decimal form, namely $\frac{1}{3}=0.3$. After that, this teacher chose the fraction $4 \quad \mathrm{X} 5$ of $\frac{5}{6}$. However, since $\frac{5}{6}+\frac{1}{3}=0.8+0.3=1.1$ (closest to 1 ), he then tried to add $\frac{1}{3}$ and $\frac{4}{7}$, since $\frac{4}{7}+\frac{1}{3}=0.6+0.3=0.9$. The preservice teacher $X 5$ interpreted 'the closest number to 1 which is dissimilar to 1 ' as language representation of a fraction order (the order after $\frac{9}{10}$ is $\frac{10}{10}$ ).

The preservice teacher X11 chose $\frac{3}{4}+\frac{1}{5}=0.75+0.20=0.95$. He thought that 0.95 was the number closest to 1 that is not 


\begin{tabular}{|c|c|c|c|}
\hline Number & $\begin{array}{c}\text { Preservice } \\
\text { teachers }\end{array}$ & Preservice teachers' responses during interview & $\begin{array}{l}\text { Types of } \\
\text { obstacles }\end{array}$ \\
\hline 6 & X15 & $\begin{array}{l}\text { The preservice teacher } X 15 \text { chose the first fraction whose } \\
\text { value was close to } 1 \text {, namely } \frac{4}{5} \text {. He thought that add- } \\
\text { ing } \frac{1}{5} \text { would give a sum of } 1 \text {, so he decided to select } \frac{1}{6} \text { as } \\
\text { the second fraction. This teacher stated that the reason } \\
\text { that } \frac{4}{5}+\frac{1}{6} \text { would result in a fraction smaller than one. He } \\
\text { stated that } \frac{29}{30} \text { was the fraction located on the left side of } 1 \text { on } \\
\text { the number line. This teacher said that there was no other } \\
\text { fraction between } \frac{29}{30} \text { and } \frac{30}{30} \text {. }\end{array}$ & 01, 06 \\
\hline 7 & $\mathrm{X} 17$ & $\begin{array}{l}\text { The preservice teacher } X 17 \text { thought that the addition of } \\
\frac{1}{3}+\frac{4}{6} \text { would result in one. The preservice teacher } X 17 \\
\text { stated that the number } 1 \text { with } 0 \text { distance was the closest to } \\
\text { number } 1 \text {. }\end{array}$ & 03 \\
\hline
\end{tabular}

Based on the interview responses in Table 3 , the preservice mathematics teachers' cognitive obstacles related to the fraction sense test can be investigated further.

\section{Discussion}

Participants $\mathrm{X}_{1}, \mathrm{X}_{2}$, and $\mathrm{X}_{3}$ underwent overlapping cognitive obstacles. In Table 3 (1), the preservice teacher $\mathrm{X}_{1}$ generalised the answer by relating it to the addition of integers, so that when he needed to add fractions, he added the denominators as well as the numerators $\left(\mathrm{O}_{4}\right)$. This happened because the preservice teachers did not understand the characteristics of operations with fractions with different denominators (operational sense). This result is consistent with the research reporting that the tendency to generalise from pre-existing knowledge can lead to a contradiction when facing new knowledge (Bishop et al., 2014). Previous knowledge that is poorly understood will be one of the inhibitory factors in solving the problem (Magajna, 2013). However, the results of the present study were different from the study conducted by Bishop et al., (2014) in that besides the tendency to generalise from previous knowledge, there was an overlapping obstacle of representation from language to symbol in the interpretation of the statement 'each number can only be used once.' The answer of the preservice teacher $\mathrm{X}_{1}$ used both 3 and 4 twice $\left(\mathrm{O}_{2}\right)$, even though the question stated that 'each number can only be used once.' The cognitive obstacles related to representation from language to symbol and the tendency to generalise caused the preservice teacher $\mathrm{X}_{1}$ to answer the question incorrectly. This result corresponds to the research conducted by Murniasih, Sadijah, Muksar, and Susiswo (2018), who reported that many preservice teachers made mistakes in representation when transitioning from written language to the fraction symbol. Based on the results of the interview with the preservice teacher $\mathrm{X}_{1}$, he also encountered an $\mathrm{O}_{3}$ obstacle. He also stated that he considered 
fractions difficult, which is consistent with the studies of Fatqurhohman, Sadijah, Irawan, and Sulandra, (2017), Lortie-Forgues, Tian, and Siegler (2015), and Prayitno, Purwanto, Subanji, and Susiswo (2018).

In Table 3 (2), the preservice teacher $\mathrm{X}_{2}$ confused the numerator with the denominator $\left(\mathrm{O}_{7}\right)$. This was caused by less meaningful learning. Meaningful learning should be created in the classroom so that the students do not easily forget a particular concept (Pinilla, 2007; Subanji, 2016; Fatqurhohman, Sa'dijah, Irawan, \& Sulandra, 2017). The less meaningful learning obstacle also overlapped with the tendency to generalise $\left(\mathrm{O}_{5}\right)$. The preservice teacher $\mathrm{X}_{2}$ thought that $\frac{5}{4}+\frac{7}{6}$ was probably equal to 2 . This teacher correlated with his pre-existing knowledge of integers by saying that 2 was close to 1 .

In Table 3 (3), the preservice teacher $\mathrm{X}_{3}$ said that $\frac{11}{12}$ was the closest number to $\frac{12}{12}$ or 1 . The preservice teacher used a trial and error strategy to obtain the answer (O8), which is not wrong, but is a time-consuming way of finding the answer. The researchers asked if there might be any other fraction between $\frac{11}{12}$ and $\frac{12}{12}$. The preservice teachers answered there was no possibility of this by representing the fraction $\frac{11}{12}$ on the left side of number 1 in the number line. The preservice teacher $\mathrm{X}_{3}$ stated that after $\frac{11}{12}$, the next fraction was $\frac{12}{12}$. The researchers concluded that the preservice teacher did not understand fraction density, and encountered the obstacle known as the tendency to rely on deceptive intuition (O6), and also a language representation obstacle with the fraction order of one twelfth (O1). This case is consistent with the study of Purnomo, Kowiyah, Alyani, and Assiti, (2014) reporting that obstacles in fraction sense occurred when someone did not understand the density of fractions. However, the present research differed in that there was an overlapping between the tendencies to rely on intuitive experience when dealing with fraction density.

Based on the answer in Table 3 (4), the preservice teacher $\mathrm{X}_{5}$ faced the obstacle of trial and error (O8). This teacher wrote the answer of $\frac{4}{7}+\frac{1}{3}=$ $0.6+0.3=0.9$ because 0.9 is the only a decimal bigger than 0.9 and less than one located right on the left side of one $\left(\mathrm{O}_{1}\right)$. However, this reason is incorrect due to the existence of many decimals between 0.9 and one, such as 0.91, 0.93, 0.97 , and so forth.

The results of the interview showed that the preservice teacher X11 encountered an obstacle of language representation when interpreting order, and stated that $\frac{3}{4}+\frac{1}{5}=0.75+0.20=0.95$ was the fraction whose position was on the left side of $1\left(\mathrm{O}_{1}\right)$. The pre-service teacher $\mathrm{X}_{15}$ stated tha $\frac{4}{5}+\frac{1}{6}=\frac{29}{30}$. The researcher asked whether there were fractions between $\frac{29}{30}$ and $\frac{30}{30}$, and the teacher stated that there were none, and thus encountered an O6 obstacle. The preservice teacher contended that $\frac{29}{30}$ was the fraction order before $\frac{30}{30}$. This means that the teacher 
faced the obstacle of language representation when interpreting the fraction order ( $\mathrm{O}_{1}, \mathrm{X}_{15}$ also stated). Meanwhile, the preservice teacher $\mathrm{X}_{17}$ answered $\frac{1}{3}+\frac{4}{6}=\frac{6}{6}$. According to the result of the interview, $\mathrm{X}_{17}$ thought that $\frac{6}{6}$ is the closest number to 1 since the distance between them is 0 . Thus, it can be concluded that $\mathrm{X}_{17}$ experiences a language interpretation obstacle $\left(\mathrm{O}_{3}\right)$.

The results show that the seven preservice teachers encountered cognitive obstacles in understanding the size of fractions. Therefore, building fraction sense for preservice teachers is essential (Whitacre \& Nickerson, 2016). The cognitive obstacles of seven preservice mathematics teachers presented in Table 3 are also shown in Figure 5.

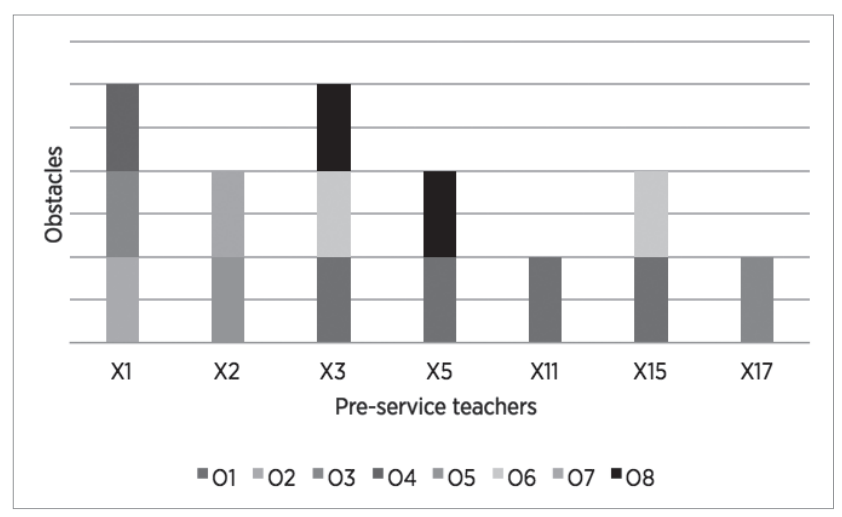

Figure 5. Cognitive obstacles of seven preservice mathematics teachers.

The research findings are further described in Figure 6.

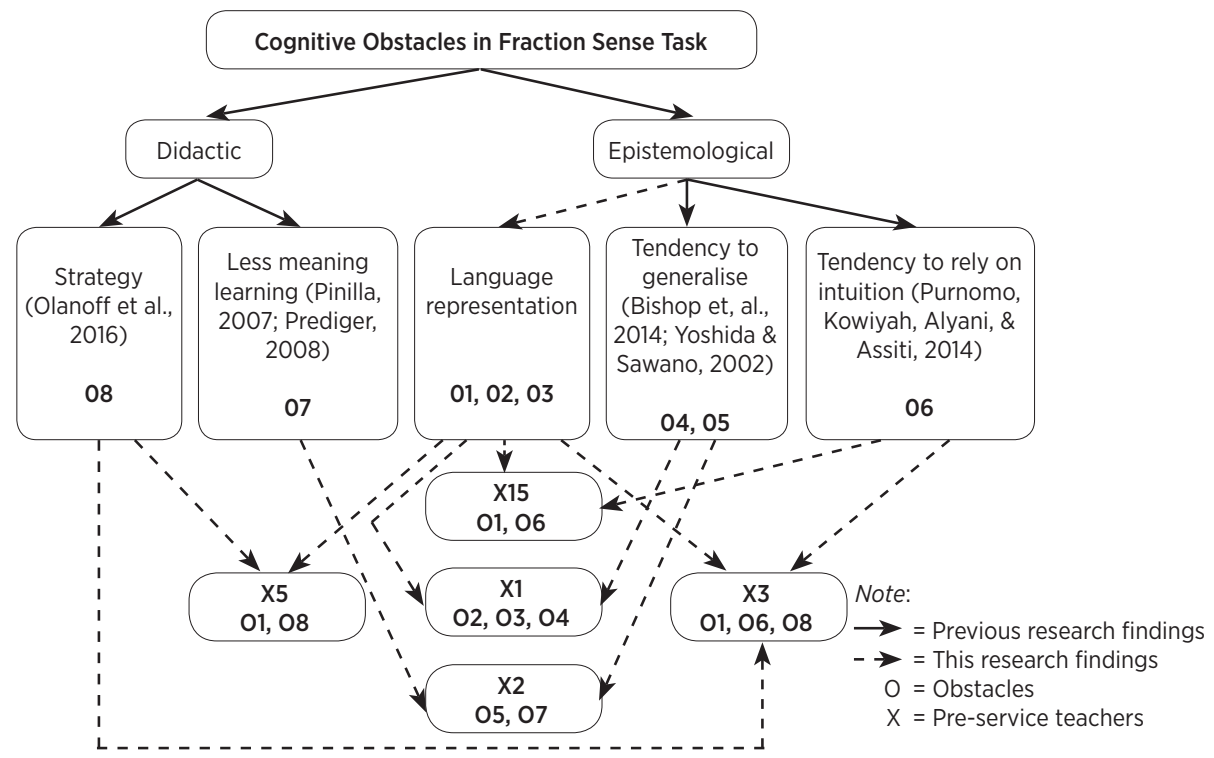

Figure 6. The overlapping cognitive obstacles in preservice mathematics teachers. 
As shown in Figure 6, the cognitive obstacles related to fraction sense in the seven preservice teachers were divided into two categories: didactic and epistemological. Generally, the three biggest obstacles encountered by the seven preservice mathematic teachers are presented in Figure 5. Those obstacles are language representation $\left(\mathrm{O}_{1}\right)$, the tendency to rely on intuition (O6), along with trial and error strategy (O8). The research also showed that the preservice teachers faced overlapping cognitive obstacles, especially teacher $\mathrm{X}_{1}$ (type $\mathrm{O}_{2}$, $\mathrm{O}_{3}$ and $\mathrm{O}_{4}$ ), $\mathrm{X}_{2}$ (type $\mathrm{O}_{5}$ and $\mathrm{O}_{7}$ ), $\mathrm{X}_{3}$ (type $\mathrm{O}_{1}, \mathrm{O}_{6}$, and $\mathrm{O}_{8}$ ), $\mathrm{X}_{5}$ (type $\mathrm{O}_{1}$ and $\mathrm{O} 8$ ), and $\mathrm{X}_{15}$ (type $\mathrm{O}_{1}$ and $\mathrm{O}_{5}$ ). This is consistent with the discussion of experts, who state that differentiating cognitive obstacles from the other types of obstacle is a complicated thing (Nyikahadzoyi, Mapuwei, \& Chinyoka, 2013). In fact, the obstacles discussed here are not easy to distinguish from one another.

\section{Conclusions}

We conclude by answering the research questions. First, this study found that preservice mathematics teachers' cognitive obstacles related to fraction sense were epistemological and didactic, which is consistent with previous research reporting that didactic obstacles in learning fractions could happen due to less meaningful learning (Pinilla, 2007; Prediger, 2008). Meanwhile, epistemological obstacles to working with fractions occurred when someone did not understand fraction density (Purnomo, Kowiyah, Alyani, \& Assiti, 2014), and could not solve new problems when contradictors arose with pre-existing knowledge (Bishop et al., 2014). Second, these results show that the types of cognitive obstacles observed were related to language representation, the tendency to generalise, the tendency to rely on intuition, strategy and less meaningful learning which are all defined as cognitive obstacles according to Brousseau (1997). These cognitive obstacles led to an incorrect answer. Based on the written answers and interview responses of the seven preservice teachers, the biggest obstacle was language representation. The obstacle related to language representation corresponds to the research conducted by Prediger and Wessel (2010), who found that a thorough understanding of language is necessary for working with fractions.

We also found that overlapping obstacles occurred in the cases of five preservice teachers. These were language representation with a tendency to generalise, a tendency to generalise with less meaningful learning, language representation with both the tendency to rely on intuitive experience and less meaningful learning, language representation with less meaningful learning, and language representation with a tendency to rely on intuitive experience. 
Third, the factors causing cognitive obstacles with fraction sense tests in preservice mathematics teachers were the preservice mathematics teachers' low level of skill with fraction sense tests, the fact that fraction sense is considered difficult by preservice mathematics teachers, and less meaningful learning. Based on the result of this study, the cognitive obstacles are overlapping with epistemological and didactic categories. This finding does not support Brousseau's theory postulating that epistemological and didactic categories are clearly separated. Further research is recommended to apply the scheme of the five big ideas from number sense to fraction sense, and use it to analyse the cognitive obstacles more thoroughly.

\section{References}

Akkaya, R. (2016). An investigation into the number sense performance of secondary school students in Turkey. Journal of Education and Training Studies, 4(2), 113-123.

Alenazi, A. A. (2016). Development of an instrument to measure fraction division operation sense. IJAEDU- International E-Journal of Advances in Education, 2(4), 32-39.

Ali, P. (2014). Assessing developmental students' number sense: A case study. National Association for Developmental Education Digest, 8(1), 2-9.

Bezpalko, O. V., Klishevych, N. A., Liakh, T. L., \& Pavliuk, R. O. (2016). Criteria and indicators of university education quality: The results of expert interview. New Educational Review, 46(4), 61-71. Bishop, J. P., Lamb, L. L., Philipp, R. A., Whitacre, I., Schappelle, B. P., \& Lewis, M. L. (2014).

Obstacles and affordances for integer reasoning: An analysis of children's thinking and the history of mathematics. Journal for Research in Mathematics Education, 45(1), 19-61.

Brousseau, G. (1997). Theory of didactical situations in mathematics. Kluwer Academic Publishers. Charalambous, C. Y., \& Pitta-Pantazi, D. (2005). Revisiting a theoretical model on fractions: Implications for teaching and research. In H. L. Chick \& J. L. Vincent (Eds.), Conference of the International Group for the Psychology of Mathematics Education (Vol. 2, pp. 233-240). PME. Chattopadhyay, K. N., Sarkar, K. C., \& Koner, S. (2017). Number sense of high school students: An assessment. International Research Journal of Interdisciplinary \& Multidisciplinary Studies (IRJIMS), III $(\mathrm{V}), 212-218$.

Clarke, D., Roche, A., \& Mitchell, A. (2011). Fractions: teaching for understanding. The Australian Association of Mathematics Teachers Inc.

Cornu. (1991). Limits. In H. Bauersfeld, J. Kilpatrick, G. Leder, S. Tumau, \& G. Vergnaud (Eds.), Advanced mathematical thinking. (pp. 153-166). Kluwer Academic Publishers.

Cortina, J. L., Visnovska, J., \& Zúñiga, C. (2014). Equipartition as a didactical obstacle in fraction instruction. Acta Didactica Universitatis Comenianae Mathematics, 14(1), 1-18.

Courtney-Clarke, M., \& Wessels, H. (2014). Number sense of final year preservice primary school teachers. Pythagoras, 35(1), 1-9. 
Fatqurhohman, Sa'dijah, C., Irawan, E. B., \& Sulandra, I. M. (2017). Representation of secondary school students in solving fractions. International Journal of Innovation in Science and Mathematics, $5(6), 172-176$.

Fennell, F. S., \& Karp, K. (2017). Fraction sense: Foundational understandings. Journal of Learning Disabilities, 50(6), 648-650.

Iuculano, T., \& Butterworth, B. (2011). Rapid communication: Understanding the real value of fractions and decimals. The Quarterly Journal of Experimental Psychology, 64(11), 2088-2098. Lamberg, T., \& Wiest, L. R. (2014). Dividing fractions using an area model: A look at in-service teachers' understanding. Mathematics Teacher Education and Development, 17(1), 30-43.

Lemonidis, C., Tsakiridou, H., \& Meliopoulou, I. (2018). In-service teachers' content and pedagogical content knowledge in mental calculations with rational numbers. International Journal of Science and Mathematics Education, 15(83), 1-19.

Lortie-Forgues, H., Tian, J., \& Siegler, R. S. (2015). Why is learning fraction and decimal arithmetic so difficult? Developmental Review, 38(4), 201-221.

Magajna, Z. (2013). Overcoming the obstacle of poor knowledge in proving geometry tasks. Center for Educational Policy Studies Journal, 3(4), 99-116.

Manfreda Kolar, V., Hodnik Čadež, T., \& Vula, E. (2018). Primary teacher students’ understanding of fraction representational knowledge in Slovenia and Kosovo. Center for Educational Policy Studies Journal, 8(2), 71-96.

Milles, M.B. \& Huberman, A.M. 2009. Analisis data kualitatif [Qualitative data analysis]. UI-Press. Murniasih, T. R., Sa'dijah, C., Muksar, M., \& Susiswo, S. (2018). Errors in representation translation in solving problems related to number sense of preservice math teachers. Annual Conference on Social Sciences and Humanities (ANCOSH) (pp. 393-399). SCITEPRESS - Science and Technology Publications, Lda. A.

Newton, K. J. (2008). An extensive analysis of preservice elementary teachers' knowledge of fractions. American Educational Research Journal, 45(4), 1080-1110.

Nyikahadzoyi, M. R., Mapuwei, T., \& Chinyoka, M. (2013). Some cognitive obstacles faced by “a” level mathematics students in understanding inequalities: A case study of bindura urban high schools. International Journal of Academic Research in Progressive Education and Development, 2(2), 2226-6348.

Olanoff, D., Feldman, Z., Welder, R., Tobias, J., Thanheiser, E., \& Hillen, A. (2016). Greater number of larger pieces: A strategy to promote prospective teachers' fraction sense development. In M. B. Wood, M. E. E. Turner, M. Civil, \& J. A. Eli (Eds.), Annual meeting of the North American Chapter of the International Group for the Psychology of Mathematics Education (pp. 799-805). The University of Arizona.

Ontario Ministry of Education. (2016). A guide to effective instruction in mathematics, grades 1 to 3 number sense and numeration. Queen's Printer for Ontario.

Ormond, C. (2012). Developing "algebraic thinking": Two key ways to establish some early algebraic ideas in primary classrooms. Australian Primary Mathematics Classroom, 17(4), 13-22. 
Osana, H. P., \& Royea, D. A. (2011). Obstacles and challenges in preservice teachers' explorations with fractions: A view from a small-scale intervention study. Journal of Mathematical Behavior, 3o(4), 333-352.

Pinilla, M. I. F. (2007). Fractions: Conceptual and didactic aspects. Acta Didactica Universitatis Comenianae, $7(1), 23-45$.

Prayitno, L. L., Purwanto, P., Subanji, S., \& Susiswo, S. (2018). Identification errors of problem posed by prospective teachers about fraction based meaning structure. International Journal of Insights for Mathematics Teaching, 1(1), 76-84.

Prediger, S. (2008). Discontinuities for mental models - A source for difficulties with the multiplication of fractions. In D. D. Bock, B. D. Sondergaard, B A. Gomez, \& C. C. L. Cheng. ICME Research and Development of Number Systems and Arithmetic (pp. 29-36). Monterrey.

Prediger, S. (2008). The relevance of didactic categories for analysing obstacles in conceptual change: Revisiting the case of multiplication of fractions. Learning and Instruction, 18(1), 3-17.

Prediger, S., \& Wessel, L. (2010). Relating registers for fraction - Multilingual students on their way to conceptual understanding. ICMI Study 21 - Mathematics and Language Diversity (pp. 324-333). Sao Paulo. Purnomo, Y. W., Kowiyah, Alyani, F., \& Assiti, S. S. (2014). Assessing number sense performance of Indonesian elementary school students. International Education Studies, 7(8), 74-84.

Rodrigues, J., Dyson, N. I., Hansen, N., \& Jordan, N. C. (2017). Preparing for algebra by building fraction sense. Teaching Exceptional Children, 49(2), 134-141.

Sa'dijah, C. (2013). Kepekaan bilangan siswa SMP melalui pembelajaran matematika kontekstual dan mengintegrasikan ketrampilan berpikir kreatif [Number sense of junior high school students through contextual mathematics learning integrates creative thinking skills]. Jurnal Pendidikan Dan Pembelajaran, 20(2), 222-227.

Sbaragli, S., Arrigo, G., D ’amore, B., Isabel, M., Pinilla, F., Frapolli, A., Frigerio, D., \& Villa, O. (2011). Epistemological and didactic obstacles: The influence of teachers' beliefs on the conceptual education of students. Mediterranean Journal for Research in Mathematics Education, 10(1), 1-2.

Simon, M. A. (2006). Key developmental understandings in mathematics: A direction for investigating and establishing learning goals. Mathematical Thinking and Learning, 8(4), 359-371. Simon, M. A., Placa, N., Avitzur, A., \& Kara, M. (2018). Promoting a concept of fraction-as-measure: A study of the learning through activity research program. Journal of Mathematical Behavior, 52(4), 122-133.

Şengül, S. (2013). Identification of number sense strategies used by preservice elementary teachers. Educational Sciences: Theory \& Practice, 13(3), 1965-1974.

Sengul, S., \& Gulbagci, H. (2012). An investigation of 5th grade Turkish students' performance in number sense on the topic of decimal numbers. In G. A. Baskan, F. Ozdamli, Sezer Kanbul, \& D. Özcan (Eds). Procedia - Social and Behavioral Sciences (pp. 2289-2293). Elsevier Ltd Son, J., \& Lee, J. (2016). Preservice teachers' understanding of fraction multiplication, representational knowledge, and computational skills. Mathematics Teacher Education and Development. 18(2), 5-28. 
Subanji. (2016). Peningkatan pedagogical content knowledge guru matematika dan praktiknya dalam pembelajaran melalui model pelatihan TEQIP [Improved pedagogical content knowledge teacher mathematics and practices in learning through TEQIP training model]. Jurnal Ilmu Pendidikan, 21(1), 71-79.

Way, J. (2011). Developing fraction sense using digital learning objects. The Australian Association of Mathematics Teachers Inc.

Whitacre, I., \& Nickerson, S. D. (2016). Investigating the improvement of prospective elementary teachers' number sense in reasoning about fraction magnitude. Journal of Mathematics Teacher Education, 19(1), 57-77.

Woodward, T. L. (1998). An exploration of grade 8 students' fraction sense. Simon Fraser.

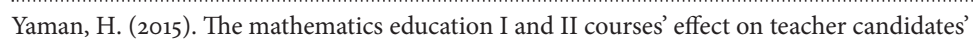
development of number sense. Educational Sciences: Theory \& Practice, 15(4), 1119-1135. Yang, D. C., Reys, R. E., \& Reys, B. J. (2009). Number sense strategies used by preservice teachers in Taiwan. International Journal of Science and Mathematics Education, 7(2), 383-403.

Yoshida, H., \& Sawano, K. (2002). Overcoming cognitive obstacles in learning fractions : Equalpartitioning and equal-whole. Japanese Psychological Research, 44(4), 183-195. 


\section{Biographical note}

TAtik Retno Murniasin is a doctor candidate of mathematics education, Faculty of Mathematics and Natural Sciences, Universitas Negeri Malang, Indonesia. She currently works at the Faculty of Education at University of Science and Technology Universitas Kanjuruhan Malang, Indonesia. Her research interests include mathematical problem solving, thought processes, translational representation in fractions, error analysis and the use of media in learning mathematics.

CHOlis SA'DIJAH, Dr, is a professor in the field of mathematics education, Faculty of Mathematics and Natural Sciences, Universitas Negeri Malang, Indonesia. Her main areas of research include research and development, mathematics assessment, creative thinking, problem solving, open ended problems and higher order thinking skill.

Makbul Muksar, Dr, is an associate professor in the field of mathematics, Faculty of Mathematics and Natural Sciences, Universitas Negeri Malang, Indonesia. His research interests include thought process, the fraction construction, the error characteristics of the fraction concept, and the fraction representation.

Susiswo, Dr, is an associate professor in the field of mathematics education, Faculty of Mathematics and Natural Sciences, Universitas Negeri Malang, Indonesia. His research interests include development of mathematics learning media, mathematical problem solving, thought process, error analysis, cognitive conflict characteristics, critical thinking and intervention on fraction concepts. 